\title{
International organizations as sui generis subjects of international law
}

\author{
MARKO AĆIĆ \\ PH.D. \\ University of Business Studies, Banja Luka \\ acicdominus@gmail.com
}

Keywords: $\quad$ international organizations, responsibility, constitutive elements, subjectivity, jurisdiction, supranationalism

Abstract: $\quad$ This paper deals in detail with the concept and the most important characteristics of international organizations as subjects of international law. Aware of the fact that a lot has already been written about this sui generis subject of international law, we will try to contribute to an even better understanding of this complex concept in a study carried out with the method of functional analysis and induction. This will be done by emphasizing the importance of constitutive elements, subjectivity, responsibilities, jurisdiction, and supranationalism of international organizations. We will also propose, as an expression of freedom of scientific thought, some de lege ferenda solutions related to the work of officials in international organizations, all with the aim of further progressive development of international law. In particular, the synthetic and comparative method will support a set of hypotheses and emphasize the supranationalism of international organizations, exemplified by the practice of the EU functioning.

\section{Organizacje międzynarodowe jako sui generis podmioty prawa międzynarodowego}

Słowa kluczowe: organizacje międzynarodowe, odpowiedzialność, elementy konstytutywne, podmiotowość, jurysdykcja, supranacjonalizm

Abstrakt: $\quad$ W artykule ukazano szczegółowo pojęcie i najważniejsze cechy organizacji międzynarodowych jako podmiotów prawa międzynarodowego. Mając świadomość, że na temat sui generis podmiotu prawa międzynarodowego napisano już wiele, postarano się w jednym opracowaniu przyczynić się do jeszcze lepszego zrozumienia tej złożonej koncepcji za pomocą metody analizy funkcjonalnej i indukcji. Dokonano tego przez podkreślenie znaczenia elementów konstytutywnych, podmiotowości, odpowiedzialności, jurysdykcji i ponadnarodowości organizacji międzynarodowych. Zaproponowano także, jako wyraz swobody myśli naukowej, pewne rozwiązania de lege ferenda dotyczące pracy urzędników organizacji międzynarodowych, a wszystko to w celu dalszego postępu w rozwoju 
prawa międzynarodowego. W szczególności metoda syntetyczno-porównawcza wsparła postawione hipotezy i podkreśliła ponadnarodowość organizacji międzynarodowych na praktycznym przykładzie funkcjonowania UE.

\section{Introduction}

In the current scientific and professional literature, international organizations are discussed from various perspectives to confirm the importance of one or more of their elements, especially concerning issues widely studied in the field of international law. The author suggests the basic hypothesis of the paper already in the title, in order to clearly emphasize that, according to him, the sui generis character of international organizations, largely determines the importance that they have today as subjects of international law. Aware of the facts and significance of previous works, we will try to contribute to the clarification of the importance and role of international organizations, precisely conceived as sui generis subjects of international law. We will analyze the propounded hypothesis especially by considering the specifics of the existing and, in our opinion, new constitutive elements of the international organizations, related to the subjectivity, jurisdiction, and responsibility of these organizations. At the end of the paper, we will try to summarize all the previously mentioned aspects of international organizations, placing them in the specific context of supranationalism, which, as a concept, is increasingly associated with the work of primarily universal (but also regional) international organizations. All this requires the use of recognized scientific research methods, above all, functional analysis, induction as a synthesis, and a comparative method. By combining the elements of functional analysis and induction, as well as emphasizing each of the particular constitutive elements of international organizations, the author wants to explain this very complex concept, which in this paper was qualified as sui generis. Pointing to the new element of the international organizations, i.e. the number of their employees, additionally emphasizes the method of analysis of the set hypothesis. This concept of work will enable us, in the end, to look at the historical context of international organizations (hereinafter: the IO) comparatively and synthetically, and to present them in current topics in international law. All of the above aims to show what role the IOs play in the integration processes, i.e. in the relations of the basic subjects of international law as exemplified by the practice of the foundation, development, and operation of the European Union as such.

\section{On the concept of international organizations}

Today, it is perhaps the most difficult to answer in a precise way the basic questions: what the IOs are (Klabbers, 2002, pp. 7-13), what they have been engaged in, and since when they are present in the international community and international processes. We can see the presence of the IO in what we call the international community, especially from the beginning of the $20^{\text {th }}$ century when the first universal IO, the League of Nations, was founded, until the new chapter in their development, i.e. the foundation of the United Nations. As Brownlie points out: "During 
historical development, international law as a whole has been influenced by the demands and progressive collective activities of states as well as non-state entities, which ultimately led to the creation of international organizations" (Brownlie, 1990, p. 680).

On the other hand, Avramov and Kreća primarily emphasize that: "IOs reflect the contradictions of the community of independent states, but also their relative unity based on knowledge of common destiny and the need for universal cooperation as a prerequisite for their own existence" (Avramov, Kreća, 2003, p. 174).

And not only that. According to Bartoš "the appearance of the IOs is a reflection of the democratization of society on a global scale, and the subjectivity of these organizations has many special features and various scopes, almost always narrower than the scope of the subjectivity of a sovereign state" (Bartoš, 1956, p. 359). We can also state that "the modern concept of international organizations is the result of evolution in the cooperation between states over a period of almost one and a half century, in response to rapid and great changes in the modern world" (Stojšić-Dabetić, 2015, p. 12). Notwithstanding these and other attitudes that emphasize the role of the IOs in various regional or global political processes, their role has not lost its significance in these processes to date. Their definition is still, due to the impossibility of accepting a universal definition, remaining related to the specific "context" (Schermers, 1980, p. 7) in which such a definition is made. Aware of the facts and the current systematics of the discussed issues related to the IOs, in this short study we will try to point out only the most important characteristics of the IOs, and we will add some scientific ideas (de lege ferenda) that should serve formulating a more comprehensive definition of the actual role of the IOs.

Precisely, for all the above reasons, a detailed consideration of the concept of $\mathrm{IOs}^{1}$ and their historical development, as well as their classification, will be omitted. However, due to the arguments that speak of the need to define the concept of IOs, we believe that it is most appropriate to agree, at this point, with the definition of Lauterpacht given during his active participation in the work of the Commission dealing with the codification of contract law. He emphasizes that "international organizations are entities created by a treaty of states, whose members are primarily states, which have permanent bodies and whose international subjectivity is recognized either by a constitutive instrument or by a treaty between a state and an organization" (Lauterpacht, 1953, p. 2). All this has led to the fact that the IOs have "gradually achieved moderate growth in the practice of international law, and got involved in all domains of international relations" (Lach, 2015) together with the establishment and peacekeeping.

1 A number of definitions of the term IO can also be found in the document of the special rapporteur A. El Erian to the United Nations General Assembly in 1963 entitled Document A/CN, 4/161 and Add 1, Special Rapporteur, published in the Yearbook of the Commission for International Law. The author, in a special part related to their definition, reports the views of several international experts, starting with Brayerli, Fitzmaurice, etc. 


\section{The subjectivity of international organizations}

To explain this complex issue, it is necessary to emphasize that throughout the entire period of traditional international law, and even later, the prevailing understanding was that subjectivity was recognized only to the states. Within this understanding of the opinion of legal writers, they took the position that the subject of international law should be considered only an "individual who can actively participate in a particular legal relationship, to be a direct holder of rights and obligations and able to exercise their rights through the capacity to act in person" (Avramov, Kreća, 2003, p. 73).

The progress of human civilization, supported firstly by economic development, over time has led to the abandonment of this understanding and the acceptance of the IOs as subjects of international law. In the international legal theory, there were two opposing views regarding the recognition of the subjectivity of the international organization: positive and negative. The predominant positive viewpoint was accepted by a large number of international legal domestic and foreign experts ${ }^{2}$. The directly related issue, the importance of which we must emphasize here, is also related to the source of international legal subjectivity and contract law or, on the other hand, to customary law.

Regardless of the source of the international legal subjectivity of the IOs, it is necessary to point out that it, as such, can be realized on a domestic and international level. The realization at the internal level depends on the "provisions of domestic law and, on the other hand, on international agreements” (Dimitrijević, Račić, Đerić, Papić, Petrović, Obradović, 2007, pp. 101-103) that refer to this issue. In general, this issue at the internal level (which is related to the issue of achieving the subjectivity of the IO) in most cases depends on the relationship between the monist and dualist concept in the internal legal system, and on the manner and scope of incorporating the international acts into their own legal systems. Without going into deeper elaboration of this issue, we can report in principle two views: "Only states have original (actual) legal subjectivity, while when it comes to international organizations we can talk about a derived or derivative international legal subjectivity, that is constituted only by the will of member states" (Mijović, 1996, pp. 16).

Other authors, however, state otherwise: "International organizations have international subjectivity, to the extent granted by the founders, either through an explicit provision in the constitutive treaty or in some other way" (Amerasinghe, 1996, p. 83; Schremers, Blokker, 1995, p. 975; Bowett, 1970, pp. 301-309).

The status of a subject of international law is determined by some of the most important international organizations, such as the United Nations (hereinafter: the UN), in their statutory documents. Regardless of the differences that can be noticed in the statutes of individual international organizations regarding the determination of legal subjectivity, it should be emphasized that in those statutes which "generally speak about legal capacity or status of a legal entity, this generality is often specified later by international conventions, additional protocols, and even

${ }^{2}$ Hudson, Alfaro, Cassesse, Andrassy, Janković, Magarašević, and others. 
headquarters agreements" (Dimitrijević, Račić, 2011, p. 24) which these IOs contract and conclude with the receiving countries. Article 104 of the UN Charter states that: "The Organization shall enjoy in the territory of each of its Members such legal capacity as may be necessary for the exercise of its functions and the achievement of its purposes" (United Nations Declaration, Article 104).

This is supported by Article 105 of the same Charter, which gives officials, as representatives of such a specific UN subjectivity, a large range of privileges and immunities that they need to perform their functions related to the UN itself. Considering the IO as a legal entity and as a participant in international relations, it should be emphasized that a special feature of a legal entity is mentioned by other conventions (Convention of the privileges and immunities, Vol. I, pp. 16-33; Vienna Convention on the law treaties between states and international organizations or between international organizations, UN Publications Sales, 2005, Vol. 5). In one of them, the Convention on the Privileges and Immunities of the UN, Article 1 states that the UN will have a legal entity. This applies in particular to the conclusion of treaties, and acquisition and disposal of movable and immovable property together with conducting legal proceedings. In addition to this status of the UN, "such a certain legal entity has specialized agencies (including technical institutions) in the UN system" (Janev, 2009, pp. 29). This is not surprising, precisely because the creators of "the statutes of these organizations, and their statutory forms in the classical usual form, made them like a reduced UN Charter, as a specific IO with a special subject of action" (Janev, 2009, p. 289). The exercise of these jurisdictions and the manifestation of their subjectivity "the IOs can share with other international organizations" (Slomason, 2011, pp. 131). This is the case, for example, with an UN Security Council Resolution No. 1831, which refers to the extension of the UN mission in Somalia, with the cooperation and necessary decision-making of the bodies of the African Union.

An important moment, in favor of recognizing this subjectivity of the IO, is the adoption of an advisory opinion of the International Court of Justice in 1949 regarding the damage suffered in the UN service, which states that the UN is a subject of law, which implies that it can acquire rights and take over obligations, and to exercise these rights by submitting various international requirements to the competent authorities. In this advisory opinion, the International Court of Justice emphasizes that all rights and duties of organizations such as the UN must be exercised under their statutory (constitutional) documents, referring primarily to the adopted goals and functions given in the UN Charter. The Court particularly emphasizes the opinion of 1949 according to which: "The Fifty States, representing the vast majority of the members of the international community, may, by international law, constitute an entity possessing objective international legal subjectivity, and not merely an entity recognized only by them".

The development of international law throughout history has been influenced by international life, and the progressive increase in the collective activities of states has already provided examples of action taken internationally through certain non-state actors. This development led in June 1945 to the formation of an international organization whose goals and principles are set 
out in the UN Charter. To achieve these goals, the Organization must have international subjectivity (ICJ, 1949).

Regardless of the time of adoption and the fact that it referred only to the UN, this advisory opinion can serve as a basis for considering subjectivity of other IOs, whether they have a regional or continental or universal character, with emphasis that this issue must be considered in close connection with their highest statutory acts. Because, as Andrassy points out, under the pressure of this opinion "and all other realities, the views on the international organization as an independent subject of international law, i.e. the holder of legal and business capacity in its own name, had to change" (Andrassy, 1976, pp. 60).

In the end, we conclude that today, the role of international organizations at the global and regional level is one of the reasons why the traditional notion of only the state as a subject of an IO is abandoned, which was prevalent not so long ago, in the $20^{\text {th }}$ century. Other authors agree with this view, including Velens, who states that this role and importance of the IOs has led to "deviation of the international legal system from the traditional" (Wellens, 2004, p. 2) understanding and linking subjectivity to the state.

\section{Constitutive elements}

The specificity of IOs as subjects of international law rests on their constitutive elements. We will point out only their most important characteristics to understand, as clearly as possible, the role of IOs as a sui generis subject. Unlike determining the definition and subjectivity of IOs, most authors agree on their essential basic elements. We will expand these previously known elements with another term, leaving the scientific public to analyze the proposed. We consider the most important constitutive elements of international organizations: the state, international treaty, permanent bodies, field of activity, special status, and, in our opinion, an adequate number of international officials (intended by the author as one of the de lege ferenda solutions).

Within the IOs, i.e. intergovernmental organizations, the state is one of the most important elements that distinguishes them from other types of IOs such as non-governmental or transnational organizations. It is important to emphasize that only sovereign states can appear as founders of interstate organizations. However, regardless of the founders, the members of these international organizations are also international legal entities that are not recognized by all other states. An example is the admission of the Republic of Bosnia and Herzegovina to the UN in 1992, despite it did not have all the elements of a sovereign state, or the admission of Kosovo and Metohija ${ }^{3}$ to the International Monetary Fund and the World Bank although it is not even a member of the UN and has not been recognized by many sovereign states.

We emphasize that it is important for the state, as a constitutive element of an IO, that in its establishment, there is a relationship between "three or more states because the association of two states is a bilateral international agreement" (Mijović, 1996, pp. 11). Regardless of the size,

3 In accordance with the UNSC Resolution No. 1244. 
economic strength or influence in international relations "from the point of view of the science of international organizations that focuses on the structure and institutionalized processes of multilateral negotiation and decision-making" (Račić, Dimitrijević, 1980, p. 18) in any case remains the most important fact that a sovereign state emerges as the founder of an IO.

Regardless of the name of the international treaty used for establishing IOs, i.e. whether we are talking about a charter, statute, constitution, etc., a multilateral international treaty ratified by the signatory states is also one of the essential elements for the establishing and functioning of all IOs. However, we must point out that there are rare exceptions where international organizations are not established by a multilateral international agreement, as is the case with the Organization for Security and Cooperation in Europe OSCE and the Commonwealth. The fact that IOs are formed based on international treaties, implies that they are completely subject to the regulations of international law whose integral part is international treaty law. Precisely because of these strict regulations and procedures of international treaty law, the process of revising the founding treaties of an IO is, in any case, rare and complicated. An international organization statute could be changed over time only by a decision of the majority of member states, and this number changes very often depending of the number of founding states. The resulting changes are most often related to the functioning of the IO bodies, whose number changes due to the increase of member states, and as a cause of that process, there occur changes related to the number of states necessary for the decision-making majority in each IO.

Permanent bodies, that function on a periodic or continuous basis, represent a condition for achieving the most important goals and tasks of any IO. It is the work of these bodies, consisting in the realization of the entrusted tasks, that allows IOs to differ from some seemingly similar institutions such as international congresses and conferences or "international multilateral treaty relations of legislative or other nature, implemented by the signatory states themselves without the intervention of a specially established body, on the other side". Within the IO, there are plenary, executive, and administrative bodies and some organizations have a statutory system for resolving disputes that may arise as a result of the subjectivity of the international organization itself. Most IOs relate the full use of membership rights, through participation in the work of its bodies and decision-making, to the payment of membership fees by each member state.

In the event that the state does not pay its monetary obligations to the IO, in which it has the status of a full member, it may be allowed to participate in the work of the IO bodies, but without the right to vote.

The field of activity represents, in a certain way, the comprehensiveness of the goals and tasks that the international organization needs to deal with in its work. Nevertheless, irrespective of this connection with the statutory norms which determine the goals, principles, tasks, or functions, the field of activity itself perhaps best reflects the very essence of the work of the IO. This field of activity can change and broaden over time if the organization itself goes through evolutionary or devolutionary developmental stages. This was the case with organizational and substantial changes in the fields of activity of the European Communities and their evolution into what we know today as the European Union. 
The special status (as one of the elements of the definition of IOs) has certain specifics that help distinguish these organizations from the previously mentioned similar organizational forms of connection, such as transnational organizations. Not wanting to repeat the basic principles of recognized international subjectivity of IOs, we only state that in the category of defining special status, elements of the subjectivity of IOs are upgraded with several other legal concepts such as the issue of privileges and immunities enjoyed by the same international organizations, rights concerning the very conclusion of international agreements, and a specific system of relations relating to the relations of IOs and their officials, which the author, unlike others, considers a special element of the IO.

We believe that a certain number of officials in the composition of each international organization is inseparable from other elements of the IOs. We support our views with the fact that, depending on the goals defined by its general acts, as well as on the scope of tasks concretized by international organizations in its headquarters and outside, they would realize their activity to a much lesser extent if they did not rely on the efficiency and permanence of engaged officers to realize planned goals and tasks as efficiently as possible. This specificity of IOs officials, which is inextricably linked to IOs by the system of privileges and immunities, forms an inseparable set of regulations that, among other things, leads the author to such a conclusion. The international organization officials are very different from other administrative and managerial staff in, for example, transnational and international non-governmental organizations, who certainly cannot be as important for the functioning of these organizations as we think international officers are for IOs. Without an adequate number of international officials representing the international organization in the field of activity and without their contribution to the development of the IO itself and the improvement of the realization of its goals, in our opinion, IOs would have a completely different essence and significance. By analyzing any organizational scheme of an IO, we can see that all categories of employees of an IO in the best way form the very essence of an international organization and ensure its operation and success both inside and outside the headquarters. Their independence from the receiving state, the state in which they are based, as well as the states whose citizenship they have, further convinces us that this is a special status that has evolved but has not yet been confirmed as a constitutive element of an international organization.

\section{Jurisdiction of the 10}

Although jurisdiction of the IO is closely related to the issue of international subjectivity, we will look briefly at the issue of the jurisdiction of IOs from various perspectives. According to the author, this issue is a border area that has its support in the part of an issue related to the mentioned subjectivity, the scope of activities, and the goals themselves defined in the highest acts that establish the IOs themselves. The jurisdiction of an international organization can be personnel-moderate towards its employees and territorial over the area of its headquarters or over certain territories outside that area, as the League of Nations or the UN was through the guardianship and mandate system. 
If we look at the classifications of international organizations by the field of activity and divide them into general and specialized, this will lead to answers related to the scope of jurisdiction. Also, these organizations can be classified even more closely, according to their specific field of activity as their primary goal, which is determined by statutory acts. To give an example, looking at the UN as a universal general organization, we can conclude based on Article 1 of the UN Charter, that its specific scope of jurisdiction could be related to maintaining peace and security, developing friendly relations between nations based on respect for equality and sovereignty, achieving international cooperation in the ways defined in paragraph 3 of this Article, as well as for the UN to become a center for coordination of actions which need to be taken to achieve these goals.

In regard to the UN, in the statute of one of its specialized organizations, namely the UN Food and Agriculture Organization (FAO), through its defined goals we can see that its jurisdiction refers to a wide range of narrowly specialized tasks starting from collecting, analyzing, interpreting, and disseminating information on food and agriculture, adoption of positions on agricultural commodity agreements, and the provision of technical assistance by the governments of its member states. Observing the issue of their jurisdiction from another perspective, through the prism of statutory acts, we can say that IOs can be competent most often for concluding international agreements, passive and active right of the mission. They exercise a specific scope of power, approved by the member states. For example, the UN exercises administrative and police authority at its headquarters even though it is in the territory of the United States of America, which is regulated in particular by the UN Headquarters Agreement. Besides, the jurisdiction of IOs can consider the expression of international claims to various arbitration and tribunals, referring primarily to the possibility of international organizations to turn to the International Court of Justice in proceedings for advisory opinions.

One of the special jurisdictions of all IOs is related to the range of performing normative activities of international organizations themselves. Analyzing the rich practice of a number of the mentioned general and specialized IOs, we can see that their normative acts can be general or individual (concerning individual cases), and the obligations depend on the statute itself, which the member states have accepted. We cannot see the same level of decisions of the International Court of Justice as a specific UN body whose decisions are generally binding and resolutions passed by, as for example, of those of the Council of Europe, which, although a significant body, does not have the same weightiness and obligation. However, we must particularly emphasize that IOs, through their jurisdictions, take great care to respect human rights and freedoms. In this context, Duxbury states that: "International organizations are increasingly promoting both human rights and democratic governance as relevant principles in addressing applications for accession by non-member countries. The importance of these principles was emphasized in the 1990s by the proposal that state membership in institutions such as the UN and involvement in regional security measures should be based on adherence to certain fundamental values, including democracy" (Duxbury, 2011, pp. 1). 
Last but not least, we believe that IOs could be responsible for protecting their staff and officials, substituting for them on an international level, although in this respect also the state of which a given official is a citizen can request protection in certain procedures. Analyzing this specific issue with border elements with the subjectivity, scope of activities, and goals of the IO itself, we can conclude that the jurisdiction of IOs has increased over time and that the strength of decisions made in the exercise of this jurisdiction has advanced. All of the above has certainly contributed to the importance of IOs as sui generis subjects of international law. One of the most obvious examples of the growing importance of IOs as participants in international processes is the European integration process, which today came from the European Coal and Steel Community to a supranational entity known as the European Union.

\section{Responsibility}

The issue of responsibility of IOs is still not clearly defined today, as it is the case with the responsibility of states as basic subjects of international law. Thus, Lapaš points out that "positive international law only accepts this diversity, recognizing that legal entities in every legal order are not necessarily identical in the nature and scope of their rights" (Lapaš, 2012, p. 1760), as concluded by the International Court of Justice (Advisory Opinions, I.C.J. 1949, p. 178), ,while every codification and definition of subjects, elements of subjectivity, remains at the level of doctrine, its influence on international practice, but also its own determination by that same practice, in an attempt to reach a common functional root cause“ (Lapaš, 2012, p. 1760). One of the most important problems, which refers precisely to the responsibilities of international organizations, is primarily observed through the applicability of the principle of state responsibility to international organizations, and secondly indicates the relationship between IOs and their states (members) taking into account the division of responsibilities.

The Commission on International Law was entrusted to specify the responsibilities of IOs. It began accomplishing its task in 2002, working on codification and progressive development of the law in this field. The draft of the regulations on the responsibility of IOs was adopted at the $63^{\text {rd }}$ session of the Commission on International Law in 2011. It covered two groups of issues: the responsibility of international organizations for international illegal acts and the responsibility of states for the actions of international organizations.

We consider it necessary to point out the general facts and facts related to the international legal responsibility of the IOs themselves according to the draft regulations and responsibilities of the IOs. Article 1 of this Draft also puts the emphasis on the previously mentioned two issues. Logically, we note in Article 3 of this Draft that the IO will be responsible for any illegal act that arises as a result of the actions of the international organization. Precisely, in the opinion of the International Law Commission, this responsibility of an IO can come as a result of its performing or not performing certain actions, with the obligation to attribute such an act to an international organization and special emphasis on the fact that it must be illegal under international law. Additionally, "the attribution of action to an international organization a subjective element, 
and the violation of an international obligation an objective element, represent two main illegal acts that lead to the international legal responsibility of international organizations" (Runjić, 2015). We can conclude that the intention of the Commission was primarily to establish such a responsibility of an international organization if, above all, it had effective control over the activities of either its own bodies or its own officials or engaged forces. We can also relate this issue to the activities of peacekeeping forces through peacekeeping operations (UNPROFOR), such as the one that the UN had in Bosnia and Herzegovina in the early 1990s, and the missions that the UN had in Congo or North Korea. From the point of view of the UN, expressed through the opinion of the UN Secretary-General and related to the mentioned peacekeeping missions, we can state that the international responsibility of the UN regarding its peacekeeping operations and combat activities can be recognized only if it is conducting field operations under the exclusive and direct command of the UN. However, if UN forces act by Chapter VII of the Charter, activities carried out under the control of UN Member States shall be based solely on the Member States participating in and conducting those operations in the territory of another State. If those are operations in which one part of the forces is under the control of the UN and the other part under the control of member states that participate in a certain peacekeeping operation under the control of the UN, the so-called double responsibility or double attribution can occur. Special rapporteur Gaja (Gaja, 2004, pp. 18-19) and Amerashinge (Amerashinge, 2005, pp. 399) speak more about this in their analyzes. In this context, we are aware that we cannot cover all the important issues related to these Draft regulations. Due to the stated importance of IOs officials, which we emphasized as a de lege ferenda solution, it is necessary to point out that the Draft regulations provide ultra vires action of organs and officials of the IOs. Article 8 of the above mentioned Draft stipulates that such action shall be recognized if a body or an official act in their formal capacity, and if such action essentially exceeds their powers or is contrary to the inquiries given. Similar issues were also discussed during the codification of the International Law Commission in 2001, with reference to the previously completed codification of the Draft regulations on the Responsibility of States for International Illegal Acts, reflecting a successful decade of the Commission's work (Jones, 2013). According to the Commission on International Law, "both responsibilities, state and the responsibility of an international organization represent secondary regulations on liability in the international law. Primary liability regulations can be found in treaties for establishing international organizations, treaties of which states or IOs are members, or in international law in general" (Daurgidas, 2014). Also, there is no doubt that certain obligations exist between states and international organizations not only under international treaty law but also under customary international law, which is "based on the similarity of one country's responsibilities to another within the same sources of public international law". The reason why the Commission on International Law did not consider the issue of responsibility of member states for the actions of international organizations in this first codification is given in Article 57 of the Draft regulations on the Responsibility of States, which states: "The answer to the question posed touches the heart of the very concept of international organization and that it does not specify any issue of international legal responsibility of any state" (Runić, 2014). 
One of the first cases, in which the question of the responsibility of states for the actions of IOs was raised, was the case before the English judiciary, concerning the responsibility of member states for the actions of the International Tin Council (ITC). There we can see exactly in which direction the first court decisions on this type of liability were going. Bearing in mind that these were the first verdicts passed before the definition was formulated of the Draft regulations on state responsibility and member states' responsibility for the action of the IOs, we can see that the courts had an explicit position. Namely, starting from the position of the High Court in London, through the decision of the Court of Appeals, until the final decision of the House of Lords, it is evident that such responsibility of the state cannot exist. In that case, before the highest judicial institution in England (Watson, 1980, pp. 675-676), Lord Templeman stated that "There is no credible evidence of the existence of a regulation of international law that would impose individual responsibility on member states for non-fulfillment of financial obligations by international organizations" (Runić, 2014). In a broader analysis of the regulations on international responsibility, Ahlborn concludes: "In its work on the responsibility of international organizations, the Commission on International Law has so far, although sometimes unknowingly, made propositions that undermine the independence of international organizations, avoiding a clear legal qualification, so-called 'Regulations of the organization"'. Instead of acknowledging that these are regulations of the internal law of the organization, the Commission suggests that several important provisions of the Draft regulations of the organization should be made part of the international law (Ahlborn, 2011, pp. 56-59). Examining the above cases and other legal practices, except for the verdict in the case of Westland vs. Arab Organization for Industrialization, we can conclude that the responsibility of states for the actions of the IOs cannot be established. Shaw (2008, pp. 1202-1207) concludes similarly about simultaneous and secondary liability, and this attitude is based on the regulations of the Vienna Convention on the Law of Treaties of 1969, more precisely on its Article 34 as well as on the same article in Convention on the Law of Treaties between States and International Organizations or between International Organizations of 1986.

A special issue of shared responsibility between the state and the IO has arisen in the analyses of many authors. Their analyses raise such questions as, for example, "if states or international organizations fail to universally protect human populations from mass violations, which will be responsible, states or international organizations?". Whose task it is to react or who bears the responsibility for the consequences will be decided according to the principle of shared responsibilities (Nollkemper, Jacobs, 2011, p. 4).

\section{Supranationalism and international organizations}

Bearing in mind the scope of this paper, along with the essential characteristics of the term of the international organization as a sui generis subject of international law, we will briefly point out their practical connection with the concept of supranationalism. In the works of certain legal theorists, there has always been a desire to form exact integration projects on the border of 
international law and international relations, which would differ, in their jurisdiction and structure, from existing subjects of international law (referring primarily to states and international organizations). Such an organizational form is designed to be in direct relation not only with the states but also with the citizens of the member states, i.e. with natural persons as one of the basic subjects of the internal legal order. Indirectly, this relation is realized through the importance of IO officials who, although they are citizens of member states, in their work within the IOs bodies, have the freedom to decide regardless of the position of their state.

Looking at the Memorandums of Association, we can say that the Memorandum of Association of the European Coal and Steel Community, in its Article 9 (defining its High Authority as supranational), remains one of the most striking examples that set it in such a way "although this determinant is lost by merging the bodies of the European Communities in 1964" (Miščević, 2012, p. 261). Besides, "at the heart of such perceptions is the naive belief that law is the cause, not the consequence of social relations, and that states do not respect their international obligations because they are sovereign, not that they are sovereign because they cannot be forced to do others' will' (Dimitrijević, Račić, 2011.p. 81). The very terms 'supranationality' or 'supranationalism' should be viewed in political and organizational terms concerning regional integration projects which, for economic, political, or security benefits, take precedence over the independent action of individual sovereignties.

The consideration of the issue of supranationalism is inseparably based on the observation of the relationship between the two most important subjects of international law, i.e. based on the relationship between states and IOs. The conclusion is "that supranational organizations possess both elements of the state and elements of international organizations, and as such are positioned between these two subjects of international relations" (Jeličić, Dragutinović, 2013, p. 7). What makes supranational organizations similar to IOs is the very will of the founders which is necessary for their foundation and which is translated into their highest constitutional or statutory acts, as well as the existence of similar elements of subjectivity as in IOs (procedural, limited contractual capacity, passive law, the right of legation and its limited active form, etc.). However, with these organization we can see some differences in comparison to IO. They are, in their final integration phase, quite different from IOs in that they approximately resemble some of the forms of government, referring primarily to the forms of complex states i.e. confederations and federations.

A special feature of supranational organizations is the voluntary readiness of their founders to gradually and permanently renounce parts of their sovereignty in the evolution of a certain supranational process and transfer it to the organization they create. According to Jeličić, supranational organizations meet the criteria of a functional organization, independent functioning, and decision-making, including potential original international action to the extent transferred to them by their member states. In addition to today's European Union which, in the opinion of experts in the field of international law, is the closest to this idea of supranationalism. It is important to note that there were phases in its foundation when we could talk about the beginnings of that phenomenon, regardless of whether we are talking about the European Coal and Steel 
Community, the project of founding the European Defense Community or the existence of the European Atomic Energy Community.

We can observe considerations about such a specific character of the European Union not only in legal science but also in the views of other authors who write from the philosophical or legal-political standpoint, and who believe that the EU, as a sui generis supranational structure, does not replace nation-states, because its is composed of them, and its functioning depends on their commitment to strengthen cooperation and create EU law, and the ability to apply them to the same EU countries as its end users.

\section{Conclusion}

At the end of this brief elaboration of the theoretical and practical operation of the IOs as sui generis subjects of international law, we can conclude that these are subjects whose constitutive elements, subjectivity, responsibility, and jurisdiction indicate how the development of international law has led to a new form of subjectivity. All the clarified characteristics of the IOs, made with the application of the methods of functional analysis, induction, synthesis, and comparative method and exemplified by the EU, indicate the current relationship, role, and importance of the relationships between them and the states as until recently the only subject of international law. In that sense, regarding the European integration project that has reached the elements of supranationalism, we consider it necessary to point out the claims of Dimitrijević and Račić. They believe that, in any case, in the EU integration takes place in the field of economy, while political and security policies are still developing at the level of cooperation for which a high degree of agreement of member states is required. According to these authors, it is based only on elements of cooperation and doesn't enter the field of integration. Although states as subjects of international law have had primacy in its development so far, we can testify that IOs are becoming an increasingly "equal" subject at the regional and universal level. Aware of all differences in the constitutive elements, subjectivity, jurisdiction, and responsibilities between states and international organizations, we must state that the progressive development of international law significantly brings to the foreground the importance of both these subjects, even though IOs still retain this sui generis character.

\section{References}

Agreement between the United Nations and the United States Regarding the Headquarters of the United Nations Signed June 26, 1947, and Approved by the General Assembly October 31, 1947(1). Retrieved from: http://avalon.law.yale. edu/20th_century/decad036.asp (7.01.2021).

Ahlborn, C. (2011). The Rules of International Organizations and Law of International Responsibility. Amsterdam: Amsterdam Center for International Law.

Amerasinghe, C.F. (1996). Principles of International Law of International Organizations. Cambridge: Cambridge University Press.

Amerasinghe, C.F. (2005). Principles of International Law of International Organizations, $2^{\text {nd }}$ rev. ed. Cambridge: Cambridge University Press.

Andrassy, J. (1976). Međunarodno pravo. $6^{\text {th }} \mathrm{ed}$. Zagreb. 
Avramov, S., Kreća, M. (2003). Medjunarodno javno pravo. Beograd: Savremena Administracija.

Bartoš, M. (1956). Međunarodno javno pravo, Vol. 1. Beograd: JIP Kultura.

Bowett, D.W. (1970). The Law of International Institutions, $2^{\text {nd }}$ ed. London: F.A. Praeger.

Brownlie, I. (1990). Principles of Public International Law. Oxford, New York: Clarendon Press.

Convention of the Privileges and Immunities of the UN Adopted 1946 (2005). "UN Treaty Series", Vol. 1, 16-33. Retrieved from: https://reaties.un.org/doc/Publication/UNTS/Volume\%2011/v11.pdf (10.01.2021).

Daurgidas, K. (2014). Reputation as the Responsibility of International Organizations. European Journal of International Law, 25 (4), 991-1010. Retrieved from: http://www.ejil.org/pdfs/25/4/2543.pdf. (6.01.2021).

Declaration of the United Nations. Retrieved from: http://www.tuzilastvorz.org.rs/html_trz/PROPISI/povelja_un_lat. pdf (10.01.2021).

Duxbury, A. (2011). The Participation of States in International Organization. Cambridge: Cambridge University Press.

Dimitrijević, V., Račić O. (2011). Međunarodne organizacije. Beograd: Pravni Fakultet, Univerzitet Union i Službeni Glasnik.

Dimitrijević, V., Račić, O., Đerić, V., Papić, T., Petrović, V., Obradović, S. (2007). Osnovi Međunarodnog Javnog Prava. Beograd: Beogradski Centar Za Ljudska Prava.

International Court of Justice. Retrieved from: http://www.icj-cij.org/docket/files/4/1837.pdf (11.01.2021).

Janev, I. (2009). Statutarno uređenje međunarodnih organizacija. Beograd: Institut Za Političke Studije.

Jeličić, B., Dragutinović, Lj. (2013). Naddržavne organizacije kao subjekti međunarodnih odnosa. Novi Sad: CIVTAS.

Jones, G.H.F. Legal Personality and the Responsibility of International Organizations. Retrieved from: http://www. otago.ac.nz/law/research/journals/otago065260.pdf (3.01.2021).

Klabbers, J. (2002). An Introduction to International Institutional Law. Cambridge: Cambridge University Press.

Lach, M. (2015). International Organizations. Collected Courses of the Hague Academy of International Law. The Hague Academy of International Law. Retrieved from: http://referenceworks.brillonline.com/entries/the-hagueacademy-collected-courses/international-organizations-169-ej.9789024729760.009_377.10 (4.01.2021).

Lapaš, D. (2012). Nevladini entiteti pred vratima međunarodnopravnog subjektiviteta. Zagreb: Zbornik Pravnog Fakulteta u Zagrebu.

Lauterpacht, H. (1953). Report on the Law of Treaties. Special Rappourter A/CN.4/63. Extract from the Yearbook of the International Law Commission, 1953, Vol. 2. Retrieved from: http://legal.un.org/ilc/documentation/english/a cn4_63.pdf (4.01.2021).

Maclaine Watson \& Co. Ltd vs. International Tin Council-ITC, judgement of 26 October 1989, House of Lords, International Legal Materials, No. 29, 1980, 675-676.

Mijović, Lj. (1996). Pravni aspekti uticaja međunarodnih organizacija na državnu suverenost. Banja Luka: Magistarski Rad.

Miščević, T. (2012). Nova era međunarodnih organizacija. Beograd: Službeni Glasnik.

Nollkemper, A., Jacobs, D. (2011). Shared Responsibility in International Law: A Conceptual Framework. Amsterdam: SHARES Research Paper 03-2011, ACIL 2011-07, 4.

Račić, O., Dimitrijević, V. (1980). Međunarodne organizacije. Beograd: Savremena Administracija.

Reparation for Injuries Suffered in the Service of the UN (1949), Advisory Opinions, I.C.J. Reports.

Report of the ILC on the Work of its Fifty-Forth session (2002), Vol. 2, YILC No. 93.

Runić, Lj. Međunarodne organizacije i međunarodna odgovornost. Retrieved from: http://www.jura.kg.ac.rs/index. $\mathrm{php} / \mathrm{sr} / 1114 . \mathrm{htm}(8.01 .2021)$.

Runić, Lj. Međunarodnopravna odgovornost država članica za akte međunarodnih organizacija. Retrieved from: http://www.hrcak.srce.hr/index.php2show=clanak\&id_clanak (8.01.2021).

Schermers, H.G. (1980). International Institutional Law. Sijthoff and Nordhoff.

Schermers, H.G., Blokker, N.M. (1995). International Institutional Law, $3^{\text {rd }}$ rev. ed. Dordrecht: Martinus Nijhoff Publishers.

Second Report on Responsibility of International Organizations by Mr. Giorgio Gaja, Special Rapporteur, A/CN, 4/541. 
Security Council UN Res. 1831. Retrieved from: http:/www.un.org/en/ga/search/view_doc.asp?symbol=S/RES/ 1831(2008) (10.01.2021).

Shaw, M. (2008). International Public Law. Cambridge, New York, Melbourne, Madrid, Cape Town, Singapore: Cambridge University Press.

Slomason, W. (2011). Fundamental Perspective of International Law, $6^{\text {th }}$ ed. Wadsworth Cengage Learning.

Statute IFAO. Retrieved from: http://www.fao.org/3/a-mp046e.pdf (13.01.2021).

Stojšić-Dabetić, J.N. (2015). Međunarodna odgovornost Evropske Unije u svetlu pravila međunarodnog prava o odgovornosti međunarodnih organizacija. Ph.D. Thesis. Beograd.

The Draft Articles on the Responsibility of International Organizations DARIO (10.01.2021).

Ugovor o osnivanju Evropske zajednice za ugalj i čelik. Retrieved from: http://eur-lex.europa.eu/legal-content/RO/ TXT/?uri=URISERV:xy0022 (17.03.2021).

Vienna Convention on the Law Treaties between States and International Organizations or between International Organizations, UN Publications Sales No. E.94, Vol. 5.

Vienna Conventions on Law Treaties. Retrieved from: https://reaties.un.org/doc/Publication/UNTS/Volume\%201155/ volume-1155-I-18232-English.pdf (16.03.2021).

Wellens, K. (2004). Fragmentation of International Law and Establishing an Accountability Regime for International Organizations: The Role of Judiciary in Closing the Gap. Michigan Journal of International Law, $25,2$.

Westland Helicopters Ltd. vs. Arab Organizations for industralization, United Arab Emirates, Kingdom Saudi Arabia, Statae of Quatar, Arab Republic of Eqypt and Arab Britis helicopter Company, March 5 ${ }^{\text {th }}$, 1984, International Law Reports, No. 80, 1989, 613.

\section{Cytowanie}

Aćić, M. (2021). International organizations as sui generis subjects of international law. Acta Politica Polonica, 1 (51), 51-66. DOI: 10.18276/ap. 2021.51-04. 